E3 Journal of Agricultural Research and Development Vol. 7(2). pp. 0111-0119, April, 2017

Available online http://www.e3journals.org

ISSN: 2276-9897 (C) E3 Journals 2017

DOI: http://dx.doi.org/10.18685/EJARD(7)2_EJARD-17-011

\title{
Evaluation of milk production performance of lactating Fogera cows fed with urea and effective micro-organisms treated rice straw as basal diet
}

\author{
Lemma Gulilat and Endalew Walelign
}

Accepted 24 February, 2017

The experiment was conducted at Andassa Livestock Research Center with the main objective of evaluating the milk production performance and feed intake of Fogera cows fed on rice straw treated by urea and effective micro-organisms (EMO) as basal diet. The experiment was conducted using a randomized complete block design (RCBD) with three treatments and three replications. Blocking was based on the initial body weight of cows. Nine Fogera cows with average age, parity, initial body weight and stage of lactation was 9.3 year, $4.4,262.7 \mathrm{~kg}$ and 53.1 days, respectively used for the feeding trial were randomly assigned to three treatments. The treatments were $67 \%$ wheat bran and $33 \%$ NSC from $2 \mathrm{~kg}$ concentrate + untreated rice straw (T1), $67 \%$ wheat bran and $33 \%$ NSC from $2 \mathrm{~kg}$ concentrate +urea treated rice straw (T2) and $67 \%$ wheat bran and $33 \%$ NSC from $2 \mathrm{~kg}$ concentrate + rice straw treated by effective micro-organism (T3). Feed offers and refusals for feeding trials were recorded daily, while body weight change of cows during the feeding trial was recorded every fifteen days. The chemical compositions of the experimental feeds indicated that the untreated, urea treated and EMO treated rice straws had low (3.46\%), highest $(5.51 \%)$ and intermediate (4.48) CP contents, respectively. Feeding of Fogera cows with EMO treated rice straw resulted in significantly $(p<0.05)$ higher daily dry matter intake (8.52 kg/cow, higher daily weight gain $(27.7 \mathrm{~g} /$ day) and higher daily milk yield $(2.82 \mathrm{l} / \mathrm{day})$ when compared with those cows fed on untreated rice straw. Furthermore, cows fed with EMO treated rice straw yielded the highest net income and marginal return rate (MRR) (82.6 and 194\%, respectively). Hence, according to the results of this study feeding of lactating Fogera cows with EMO treated rice straw is efficient for both biologically and economically compared to urea treated rice straw.

Key words: effective microorganism, lactating cows, rice straw, milk yield, urea treatment

\section{INTRODUCTION}

Livestock in Ethiopia provide draught power; serve as source of income for farming communities, means of investment and important

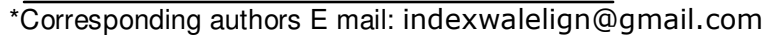

source of foreign exchange earnings. Of the total household cash income of farming community, livestock account for 37 to $87 \%$ in different parts of the country (Ayele et al., 2003). The livestock population in Amhara National Regional State (ANRS) is estimated at 10.5 million cattle, 8.2million sheep and 5.1 million goats. Of the 
cattle population in the region, about25, 744 are believed to have indigenous and exotic blood (Eshete, 2007), which is only $0.25 \%$ of the population is exotic blood and the remaining vast cattle population of the country $(99.75 \%)$ belongs to indigenous/local breed.

The Fogera cattle found in Fogera Woreda, South Gondar Zone, is used for milk, meat and draft power by smallholder farmers. They are known to have better performance in terms of milk yield, growth rate and tolerance to heat, parasitic burden and adaptability to marshy areas (Gebeyehu, et al., 2004). The Fogera cattle is one of the 27 identified indigenous breeds (a Zebu $x$ Sanga breed) in the country and is distributed in a plain around Lake Tana, northwestern Ethiopia (Gebeyehu, et al., 2004). However, the population and productivity of Fogera cattle breed is declining due to shifting of grazing land in to rice cultivation, damage of grazing land by flood and lack of adequate feeds (Firew and Getnet, 2010).

In Fogera Woreda, rice straw is the most abundant livestock feed resource. But this straw has high fiber content and low digestibility and protein content (3.35\%) (Teshome Derso, 2009). The treated low quality roughages have higher digestibility and crude protein than untreated roughages. According to AlemuYami (2008), farmers feed their high nutrient requiring animals, such as lactating or fattening animals treated low quality roughage by using different mechanism.

Therefore, rice straw can be improved by using different treatment methods like urea and effective micro-organisms. The protein content of feed treated by mixing of different treatment; the mixture of EM contained treatment had highest protein content as compared to the others (Nassia.B. et al., 2013). All the available evidences tend to indicate that EMO could safely and economically be included into animal feed. There is no environmental and public health hazard reported from the use of EM technology in animal feeding. There are experiments done on dairy cows using urea treated rice straw but no work is yet done using effective micro-organism. Hence this study was conducted with the objectives of evaluating the milk production performance and feed intake of Fogera cows provided with rice straw treated by urea and EMO and to compare the nutritive value and the economic benefits of urea and EMO treated rice straw.

\section{MATERIAL AND METHODS}

The study was conducted at Andassa Livestock Research Center which is located $11^{\circ} .4 \mathrm{~N}$ and $37^{\circ} .3 \mathrm{E}$ and is located $19 \mathrm{~km}$ from BahirDar. The minimum and maximum temperature was $22^{\circ}$ and $30^{\circ}$, respectively with annual rainfall of $1300 \mathrm{~mm}$. Before commencement of the experiment, all animas were dewormed for internal parasites and nine lactating cows with parity 4 and 5 and two weeks after calving were selected. The experimental cows were assigned to each treatment based on their initial body weight randomly and experimental cows were given experimental diets for 45 days including 15 days of adaptation and milk yield and feed intake was taken from each treatment for one month.

\section{Experimental feed preparation}

The urea treated rice straw was ensiled in polythene sheet with a capacity of $50-100 \mathrm{~kg}$ of urea treated rice straw. The ratio of water: urea: straw used was 100:5:100 $\mathrm{kg}$ as per the recommendation of Chenost (1995). The solution of urea and water was uniformly sprayed and mixed to properly incorporate the solution into the straw on batch bases with $100 \mathrm{~kg}$ of straw and water each with $5 \mathrm{~kg}$ of fertilizer grade urea. The duration of rice straw treatment was for 21 days. After 21 days, urea treated rice straw was provided for the cows based on their requirements (Misra et al. (2006).

For the preparation of effective micro-organism treatment, adequate quantities of an inert form of EM (EM-1) packed in plastic bottles was obtain from Bahir Dar its branch of Weljijie PLC (Debrezeit). The procedure was chopped the rice straw within the $2-3 \mathrm{~cm}$ length, prepared 1 litter of inactive EM and molasses and 18 litter of water. Then the molasses, EM1 and water were thoroughly mixed to activate the microorganism. After stirring, the mixture (one liter of EMO) was inoculated into or sprayed over $(50-70 \mathrm{~kg})$ of rice straw. The mixed solution was finally incubate in an airtight container for microbial fermentation and multiplication and stored for 10 days in dark room with room temperature (Higa and Wididana, 2007). 


\section{Experimental design and treatments}

The experiment was conducted by a randomized complete block design (RCBD) involving three treatments. The three treatment combinations were the following;

T1: $2 \mathrm{~kg}$ of concentrate+ $3 \%$ their body weight untreated rice straw per day/head

T2: $2 \mathrm{~kg}$ of concentrate+ $2.5 \%$ their body weight rice straw treated by urea per day/head

T3: $2 \mathrm{~kg}$ of concentrate $+2.5 \%$ their body weight rice straw treated by EMO per day/head

\section{Data Collection}

\section{Chemical composition of feeds}

All samples of feed offered and refusals were analyzed for DM, N (Kjeldahl-N) and ash content according to AOAC (1990) procedures in Bahir Dar University, Engineering Faculty, and school of Food Technology. Neutral detergent fiber (NDF), acid detergent fiber (ADF) and acid detergent lignin (ADL) were determined by the methods of Van Soest et al., (1991) in laboratory of international livestock research institute (ILRI) in Addis Ababa.

\section{Milk yield and composition analysis}

Half of the experimental cow's teat were hand milked twice a day (at 8:00 am in the morning and 4:00 pm in the evening), the left teat for the first fifteen days and right teat for the next fifteen days and the average daily milk yield per cow was calculated by multiplying the daily milk yield from half of the teat by two and milk yield measurements were taken by using graduated cylinder every day throughout the study period. The average daily milk yield of the individual lactating cow was determined dividing the total milk yield of experimental cow by the number of experimental days. Every fifteen days interval, $100 \mathrm{ml}$ of milk samples were taken using a glass measuring cylinder for each cow after the completion of the adaptation period for chemical analysis. The milk samples were used to determine percentage of fat, protein and ash. Fat content of the milk was estimated using the Gerber analytical method and the formaldehyde titration method was used to determine the total protein content of milk (Van Soest et al., 1991).

\section{Animal's body weight}

The body weights (BW) of animals were measured by using heart girth at fifteen days intervals throughout the experiment to determine BW change. Body weights were recorded for each lactating cow against its identification number on a weight registration notebook. The body weights of lactating cows were taken within fifteen days interval by overnight fasting. Body weight changes were determined as a difference between the final and initial body weight, where both measurements were taken as a sum of two consecutive weightings. The daily body weight gains (DBWG) were calculated as the difference between final BW and initial BW divided by number experimental days. The feed conversion efficiency of experimental animals was determined as the ratio of daily body weight gain to the amount of feed consumed for the total experimental days.

\section{Feed intake}

A weighed amount of feed was offered twice per day at 8:00 am in the morning and 4:00 pm in the afternoon. Orts were collected for the next morning and weighed after removing external contaminants by visual inspection. For each replicate, the feed offered and refusal were recorded. The amount of feed consumed was determined as the difference between the feed offered and refused on dry matter (DM) basis.

\section{Partial budget analysis}

The partial budget analysis was performed to evaluate the economic advantage of the different treatments by using the procedure of Upton (1979). The analysis involved the calculation of the variable costs of experimental milk, feeds and benefits gained from the result. At the end of the experiment, experienced milk dealers from Bahir Dar market estimated the selling price of experimental lactating Fogera cow's milk. In the analysis, the total return (TR) was determined by calculating the difference between selling and 
Table 1: Chemical composition of rice straw treated by EMO, urea and untreated

\begin{tabular}{cccc}
\hline Chemicals composition of & \multicolumn{3}{c}{ Treatment diet } \\
\cline { 2 - 4 } Offered feed & T1 & T2 & T3 \\
\hline DM(\%) & 91.9 & 92.8 & 92.8 \\
Ash (\%) & 18.2 & 23.3 & 21.3 \\
CP (\% DM) & 3.46 & 5.51 & 4.98 \\
CF (\% DM) & 32.1 & 15.7 & 10.5 \\
NDF (\% DM) & 69.1 & 68.0 & 56.3 \\
ADF (\% DM) & 43.7 & 46.1 & 41.0 \\
ADL (\% DM) & 4.1 & 6.4 & 4.9 \\
\hline
\end{tabular}

$A D F=$ acid detergent fiber; $N D F=$ neutral detergent fiber; $A D L=$ acid detergent lignin

purchasing price of lactating Fogera cow's milk in each treatment at the beginning and the end of the experiment. The cost of feeds was computed by multiplying the actual feed intake for the whole feeding period with the prevailing prices.

The partial budget method measures profit or losses, which are the net benefits or differences between gains and losses for the proposed change and includes calculating net return (NR), i.e., the amount of money left when total variable costs (TVC) are subtracted from the total returns (TR).

$\mathrm{NR}=\mathrm{TR}-\mathrm{TVC}$

Total variable costs include the costs of all inputs that change due to the change in production technology.

The change in net return $(\Delta N R)$ was calculated as the difference between the change in total return $(\Delta T R)$ and the change in total variable cost $(\triangle T V C)$, and this is to be used as a reference criterion for decision on the adoption of a new technology.

$\Delta \mathrm{NR}=\Delta \mathrm{TR}-\Delta \mathrm{TVC}$

The marginal rate of return (MRR) measures the increase in net income $(\Delta \mathrm{NI})$ associated with each additional units of expenditure ( $\triangle T V C)$. This is expressed in percentage as:

$\operatorname{MRR}(\%)=(\Delta \mathrm{NR}) /(\Delta \mathrm{TVC}) \times 100)$

\section{Methods of data analysis}

ANOVA for Feed intake, milk yield and composition was done using the GLM or Mixed model procedure in in SAS or SPSS software version 9.0 and differences were considered statistically significant at either $\alpha=0.05$ or $95 \%$ confidence interval.

\section{RESULTS AND DISCUSSION}

\section{Chemical composition of experimental feeds}

The chemical composition of different experimental feeds is shown in Table 1. The dry matter of rice straw treated by urea in this experiment was contradictory to the DM content of $95.5 \%$ and $69.1 \%$ reported by Teshome (2009) and Promma et al. (1993), respectively. But similar with Hany (2000) reported 91.5\% DM content of rice straw. The CP content of rice straw in this experiment disagrees with the CP content of 7.6 reported by Promma (1993); this disagreement is may be due the stage of rice harvested and the time and season differences. But agree with the $\mathrm{Cp}$ content of $3.35 \%$ and $3.5 \%$ reported by Teshome (2009) and (Yuangklang et al, 2009), respectively. The CP content of rice straw used in the current experiment is greater than the $\mathrm{Cp}$ content of $2.76 \%$ and $4.99 \%$ that reported by Parnich (1983) for untreated and urea treated rice straw, respectively. But the ADF of rice straw used in the current experiment was less than that reported by Parnich (1983) but the ADL was greater in the current finding. The fiber content of rice straw treated by effective microorganisms was low as compared to untreated rice straw.

\section{Dry matter intake}

Dry matter intake (DMI) of lactating Fogera cows fed diet containing rice straw treated by effective microorganism and urea is presented in Table 2. The daily dry matter intake of lactating cows fed rice straw treated by EMO was significantly 
Table 2: Feed intake and milk yield of Fogera cows fed untreated rice straw and treated by EMO and urea

\begin{tabular}{|c|c|c|c|c|c|}
\hline \multirow[t]{2}{*}{ Body weight } & \multicolumn{3}{|c|}{ Treatment } & \multirow[t]{2}{*}{ SEM } & \multirow[t]{2}{*}{ SL } \\
\hline & T1 & T2 & T3 & & \\
\hline TDMC (kg/cow) & 190.2 & 239.33 & 255.47 & 13.4 & Ns \\
\hline DDMI (kg/cow/day) & $6.34^{\mathrm{D}}$ & $7.98^{\mathrm{ab}}$ & $8.52^{\mathrm{a}}$ & 0.15 & * \\
\hline MY (It/Cow/day) & $2.34^{\mathrm{b}}$ & $2.4^{\mathrm{ab}}$ & $2.82^{\mathrm{a}}$ & 0.007 & * \\
\hline
\end{tabular}

${ }^{a, b}$ Means within a row with different superscripts are significantly different; $N$ s = no significant; ${ }^{*}=$ significant at $(P<0.05) ; T D M C=$ Total Dry Mater Consumed; DDMI = Daily Dry Matter Intake; $M Y=$ milk yield

Table 3: Chemical composition of milk used for different experimental treatments

\begin{tabular}{cccc}
\hline Chemical & \multicolumn{3}{c}{ Milk } \\
\cline { 2 - 4 } composition & T 1 & T 2 & T 3 \\
\hline DM (\%) & 13.12 & 15.61 & 13.56 \\
CP (\% DM) & 3.42 & 3.77 & 3.48 \\
CF (\% DM) & 3.50 & 3.63 & 3.33 \\
Ash (\% DM) & 0.70 & 0.73 & 0.75 \\
\hline
\end{tabular}

$D M=$ Dry Mater $C P=$ Crude Protein $; C F=$ Crude fat;

$(P<0.05)$ higher than untreated rice straw. The intake of rice straw in the current experiments agrees with the report of Wanpat et al, (2013). In the current experiment, the daily dry matter intake of urea treated and untreated rice straw was significantly greater than $5.65 \mathrm{~kg}$ and $4.91 \mathrm{~kg}$ per day, respectively that reported by Parnicch (1983). But daily dry mater intake of urea treated rice straw reported by Wanapat (2013) was in line with the findings of this experiment.

Feed intake is a very important factor that determines the production of milk and body weight, in cows (McAinsh and Riise, 2005). The result of the present study indicates that the feed intake as well as milk production of lactating Fogera cows increased when the rice straw was treated by urea and effective micro-organism as compared to untreated rice straw.

\section{Milk production and composition}

As we observed from the table 3 milk composition of lactating cow for feeding of urea treated rice straw had good protein content as compared to the remaining treatments. As we absorbed from the table the protein content of milk when an animal's fed urea treated rice straw was also high as compared to other treatments. This is the reason urea has nitrogen rich compound which contribute protein for milk and feed. The nitrogen content of lactating cow's milk for the current experiment was higher than $3.2 \%$ and $3.3 \%$ animals that fed untreated and urea treated rice straw, respectively reported by Wanapat (2013) and Thaintip (2013). The fat content of the current experiment was similar with the study of Hart (1992). However, the fat and protein content of milk which animal's fed urea treated and untreated rice straw was lower than that reported by Wanapat et al. (2013) and Hart (1992), on Holstein crossbred dairy cattle in Thailand and Buffalo in Australia, respectively.

Milk composition and production are the interaction of many elements within the cow and external environments (O'Connor, 1994). High milk yield of satisfactory composition is the most important factor ensuring high economic returns. If the composition of milk varies widely, its implication is that feed value and its availability as a raw material will also vary. Feeding of urea treated rice straw alone had given an extra milk yield of $1.16 \mathrm{~kg}$ in lactating animal per day in the study area, which is similar to1-1.5 kg milk per day reported by Khan and Davis (1981) and Pedock et al. (1982). Similar results were also 


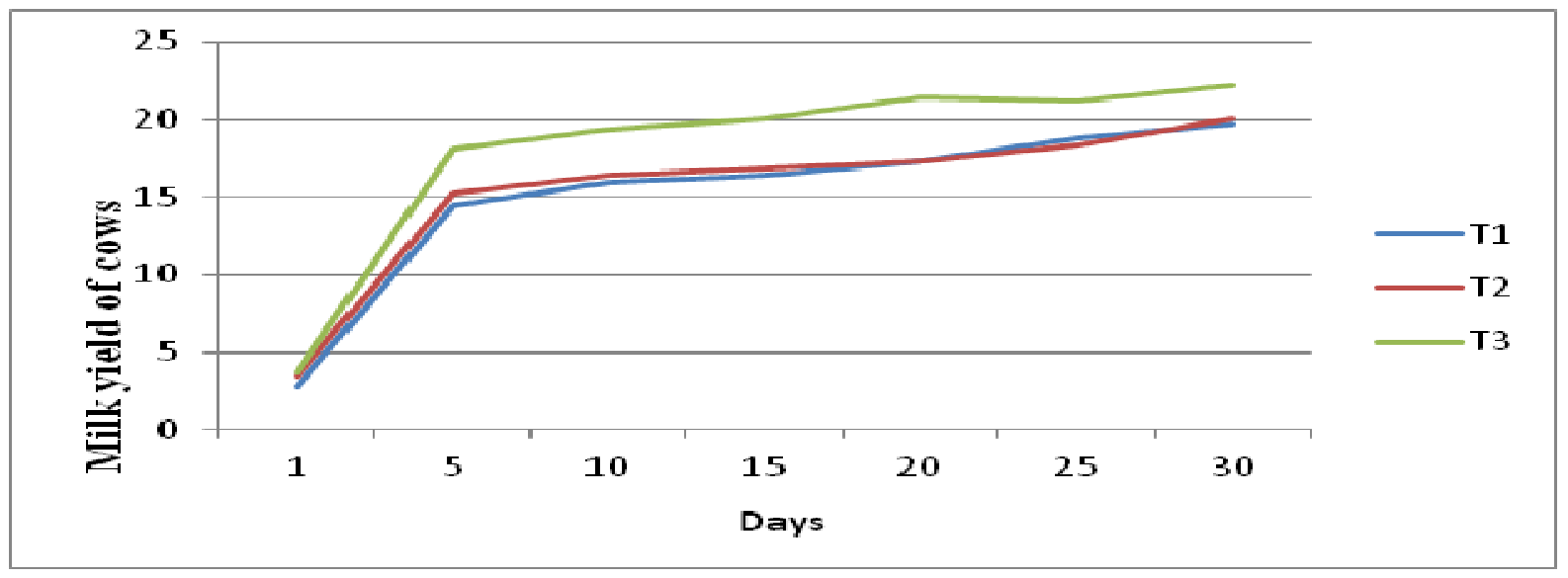

Figure 1: Feed intake and milk yield of lactating Fogera cows fed untreated rice straw and treated by EMO and urea

Table 4: Animal body weight and feed conversion efficiency of different treatments

\begin{tabular}{cccccc}
\hline Body weight & \multicolumn{3}{c}{ Treatment } & SEM & SL \\
\cline { 2 - 6 } & T1 & T2 & T3 & & \\
\hline Initial body weight $(\mathrm{kg})$ & 262.0 & 245.33 & 254.67 & 11.1 & $\mathrm{Ns}$ \\
Final body weight $(\mathrm{kg})$ & 262.4 & 245.95 & 255.5 & 11.1 & $\mathrm{Ns}$ \\
MDBWG (g) & $13.3^{\mathrm{b}}$ & $20.7^{\mathrm{ab}}$ & $27.7^{\mathrm{a}}$ & 4.7 & $\star$ \\
FCE & 0.069 & 0.086 & 0.108 & 0.02 & $\mathrm{Ns}$ \\
\hline
\end{tabular}

${ }^{a, b}$ Means within a row with different superscripts are significantly different; $N s=$ o significant; ${ }^{*}=$ significant at $(P<0.05)$; MDBWG = Mean Daily Body Weight Gain in Gram; FCE = Feed conversion efficiency

reported by Mesfin et al (2009), and Getu (2006) indicating that cows fed urea treated teff straw and wheat straw respectively had significantly higher milk yield than non-supplemented crossbred cows. In the current experiment there was significant difference $(P<0.05)$ between the cows fed on treated and untreated rice straw taking groups of cows in milk yield. The effect of inclusion of effective micro-organism treated rice straw in lactating Fogera cow's daily milk yield is depicted in Table 2 and Figure 1. Milk yield of lactating Fogera cows that fed rice straw treated by effective micro-organism was significantly $(\mathrm{P}<0.05)$ higher than untreated rice straw. Milk production in all treatments of the current experiment is similar with Teshome (2009). Different experiments showed that cows fed urea treated rice straw produced higher daily milk yields compared to cows fed untreated rice straw
(Wanapat, 2013). The milk production depends on the intake of feed. Therefore, this experiment also indicated that the milk yield increased with the increment in dry matter intake of Fogera cattle.

\section{Body weight change}

The effect of inclusion of rice straw treated effective micro-organism on body weight change of Fogera cows is represented in Table 4. According to Mukassa-Mugerwa (1989), lactating cows will probably lose weight after calving, but weight loss should be minimized through good feeding to allow them to start cycling again and to allow annual calving. During the early lactation (first three months after calving) all cows in the current study lost body weight, with a declining trend with advance in lactation. Requirements for 
Table 5: Partial budget analysis for lactating Fogera cows fed urea treated rice straw and EMO

\begin{tabular}{clll}
\hline Parameter & \multicolumn{3}{l}{ Treatments } \\
\cline { 2 - 4 } & \multicolumn{1}{c}{ T1 } & \multicolumn{1}{c}{ T2 } \\
\hline Purchasing price of milk ETB/cow & 11.16 & 11.16 & 11.16 \\
Feed consumed $(\mathrm{kg} / \mathrm{cow})$ & 255.47 & 224.53 & 251.50 \\
Rice straw consumed $(\mathrm{kg} / \mathrm{cow})$ & 255.47 & 220.13 & 239.33 \\
Total supplement consumed $(\mathrm{kg} / \mathrm{cow})$ & - & 4.4 & 11.97 \\
Labor cost ETB & 25.5 & 27.70 & 31.48 \\
Total feed cost $(\mathrm{ETB} / \mathrm{cow})(\mathrm{TVC})$ & 216.99 & 286.37 & 259.51 \\
Cost of rice $(\mathrm{ETB} / \mathrm{cow})$ & 216.99 & 186.77 & 189.88 \\
Cost of supplements $(\mathrm{ETB} / \mathrm{cow})$ & - & 99.10 & 69.63 \\
Gross income $(\mathrm{R})(\mathrm{ETB} / \mathrm{cow})$ & 422.4 & 432.6 & 508.44 \\
Total return $(\mathrm{TR})(\mathrm{ETB} / \mathrm{cow})$ & 411.24 & 419.16 & 493.84 \\
Net return $(\mathrm{NR})(\mathrm{ETB} / \mathrm{cow})$ & 194.25 & 132.79 & 234.93 \\
Change of net income $(\Delta \mathrm{NI})$ & - & 7.92 & 82.6 \\
Change of total variable cost $(\Delta \mathrm{TVC})$ & - & 69.38 & 42.52 \\
MRR $(\Delta \mathrm{NI} /(\Delta \mathrm{TVC})$ & - & 0.11 & 1.94
\end{tabular}

$T V C=$ Total variable cost $; T R=$ Total return; $N I=$ Net income $; T V C=$ change of total variable cost $\Delta \mathrm{NI}=$ change of net income; $M R R=$ marginal rate of return; $E T B=$ Ethiopian birr's $N R=$ net return

the observed daily mean milk yield $(2.31 \mathrm{~kg} /$ day $)$ from this trial were not met at all levels of supplementation; but the estimated MEI requirement $(63 \mathrm{MJ} /$ day) for maintenance and milk production of lactating dairy cow weighing $250 \mathrm{~kg}$ (average body weight of the experimental animals) and producing $4-6 \mathrm{~kg} /$ day milk of $4.5 \%$ butter fat (ARC, 1990).

The finding from this trial clearly supports this idea suggested by Preston and Leng (1986) that molasses or alkali treated straw based diets are more digestible, but they support little improvement in animal productivity unless they are supplemented with bypass nutrients. There was no significance difference in initial body weight and final body weight among treatments, but mean daily body weight gain of cows fed diet consisting rice straw treated by EMO was significantly $(P<0.05)$ higher than $T 1$. The result indicated that the daily body weight gain and feed conversion efficiency was increased when lactating cows were fed rice straw treated by urea and effective micro-organism accordingly. The findings of this experiment contradicts with the findings of Teshome (2009), who reported reduced growth rate of lactating cows when fed with untreated rice straw unlike urea treated rice straw. This discrepancy could be due to the supplementation of $2 \mathrm{~kg}$ concentrate feed in this experiment for lactating cows which were fed on untreated rice straw. The other reason in this experiment could be the short experimental period; 30 days is not enough to evaluate the change in weight of the experimental animals.

\section{Partial budget analysis}

The partial budget analysis for the feeding trial is presented in Table 5. The result of the partial budget analysis indicated that the gross financial margin or total return obtained in this trial was 411, 419, and 493 ETB/cow for lactating Fogera cows fed on T1, T2 and T3 diets, respectively.

As it is indicated from the partial budget analysis in Table 5, lactating Fogera cows fed on effective micro-organism treated rice straw(T3) returned a higher net income (234.33 ETB/cow) as compared to the other treatments .

The net return from each treatment was 194.25, 132.79 and $234.33 \mathrm{ETB} /$ head for T1, T2 and T3, respectively. The percent of marginal rate of return (MRR) was 11 and 194 for T2 and T3, respectively. Thus, it indicated that each additional unit of one ETB per liter of milk cost increment resulted in one ETB and additional 0.11 and 1.94 ETB benefit for T2 and T3, respectively. Lactating Fogera cows fed on rice straw treated by effective micro- organism (T3) had the highest net income and MRR value (82.6 and 194\%, respectively) as compared to the other treatment groups. Therefore, feeding of rice straw for 
lactating cows treated by urea and effective microorganism had better economic benefits as compared to feeding of untreated rice straw.

\section{CONCLUSIONS AND RECOMMENDATIONS}

The chemical composition of the experimental feeds indicated that the untreated rice straw had low CP $(3.46 \%)$ content which is below the maintenance requirement of animals. The urea treated had higher CP $(5.51 \%)$ contents as compared to $\mathrm{T} 1$ and $\mathrm{T} 3$; this is increases the production of milk as compared to untreated rice straw numerically. The daily mean body weight gain of animals fed on EMO treated rice straw $(27.7 \mathrm{~g} /$ day) was significantly higher $(\mathrm{p}<0.05)$ than animals fed untreated rice straw, but no significant difference was observed between the urea treated and untreated rice straw. The result of the feeding trial indicated that animals fed rice straw treated by effective micro-organism had higher $(p<0.05)$ daily dry matter intake (8.52 kg/cow/day) as compared to untreated rice straw. The total milk yield and daily milk yield of cows was significant differences $(P<0.05)$ higher in $(T 3)$ than $(T 1)$.

Lactating Fogera cows fed rice straw treated by effective micro-organism (T3) had the highest net income and MRR value as compared to the other treatment groups. Therefore, feeding of rice straw for lactating cows treated by effective microorganism had better economic benefits as compared to feeding of untreated and urea treated rice straw. Hence, we recommended that, rice straw treated by effective micro-organism is higher than urea treatment in many aspects, like its effect on milk production, feed intake, and the aroma of the treated straw is also acceptable by the animals. In addition to this it is also economically profitable and hence we recommend effective micro-organism treated rice straw as an efficient way of treating rice straw. However, further on farm trial has to be conducted to verify the on-station findings of this experiment.

\section{REFERENCE}

Alemu Yami (2008). Nutrition and feeding of sheep and goat. Ethiopia sheep and goat productivity improvement

AOAC (Association Cofficial Analytic Chemists) (1990). Official methods of analysis 15th ed, AoAC, inc.Arlington,Virginia, U.S.A. $1298 p$.
ARC (Agricultural Research Council), (1990). The nutrient requirement of ruminant livestock. Common Wealth Agricultural Bureaux. Slough, England. UK.

Ayele S, Assegid W, Belachew H, MA Jabbar and MM Ahmed (2003). Livestock marketing in Ethiopia: A review of structure, performance and development initiatives. Socioeconomic and Policy Research Working Paper 52. ILRI (International Livestock Research Institute), Nairobi, Kenya. 35pp.

Chenost M (1995). Optimizing the Use of Poor Quality Roughage through Treatments and Supplementation in Warm Climate Countries with Particular Emphasis on Urea Treatment. First Electronic Conference on tropical Feeds with Particular Emphasis on Urea Treatment. FAO, Rome.

Eshete D (2007). Assessment of dairy beef development potential in Amhara region (presented at a workshop organized by SPS-LMM and Amhara Region Agricultural Research Institute). Bahir Dar, Ethiopia.

Gebeyehu GA, Tegegne T, Mulugeta A, Agide (2004). Preliminary report on the distribution of Fogera cattle around Lake Tana, Ethiopia. Addis Ababa, ESAP. Proceedings of the 11th annual conference of the Ethiopian Society of Animal Production (ESAP), Addis Ababa, Ethiopia, 2004, 203-207.

Getu K (2006). Replacement of Formulated Concentrate Mix with Vetch (Viciadasycarpa) Hay to Lactating Crossbred Dairy Cows Fed on Urea Treated Wheat Straw. M.Sc. Thesis, Alemaya University.

Hart FJ (1992). Physiology of digestion of urea treated rice straw in Swamp Buffalo. AJAS, 1992 Vol.5 (No.4) pp617622

Higa T and GN Wididana (2007). The Concept and theory of Effective Microorganism.

Khan AKMN and Davis CH (1981) Effect of treating paddy straw with ammonia on the Performance of local and cross bred lactating cows; In: Jackson et al (editors): Maximum livestock production from minimum land.Pp168

Mesfin D, Seyoum B, Aemiro K, Getu K and Kedir N (2009). On-farm evaluation of lactating crossbred (Bostaurus $\mathrm{X}$ Bosindicus) dairy cows fed a basal diet of urea treated teff (Eragrostistef) straw supplemented with escape protein source during the dry season in crop-livestock production system of north Shoa, Ethiopia. Livestock Research for Rural Development Volume 21, Article 61. Retrieved April 5, 2009,fromhttp://www.Irrd.org//rrd21/5/deje21061.htm

Misra AK, Mehra UR and Dass RS (2006). Assessment of feeding urea ammoniated wheat straw on growth performance feed intake and nutrient utilization in cross bred calves reared under stall fed or grazing condition. Livestock research for rural development. Volume, 18 No.11. Retrieved November 1, 2008, from http://www.Irrd.org//rrd186/11/misr18164.htm

Mukasa-Mugerwa E (1989). A review of reproductive performance of Bosindicus cattle. ILCA Monograph No. 6, Addis Ababa, Ethiopia

Nasia B, Imtiaz A, Imdad H and Muhammad F (2013). Mixing less palatable grasses with urea, molasses and effective microorganisms and its effect on chemical composition and digestibility in goats.

O'Connor CB (1994). Rural Dairy Technology. ILRI Training Manual 1. ILRI(International Livestock Research Institute), Addis Ababa, Ethiopia. Pp133

Parnich T (1983). Urea-ensiledrice straw as a feed for cattle Perdock HB, M Thamothaaram, JJ Bloom, H Van Den Born 
and C Van Veliw (1982). Practical Experiences with Urea Ensiled Straw in Sirilanka. Maximum Livestock Production from Minimum Land. Pp. 123-134. Proc. of the Third Seminar Held at Bangladesh Agricultural Research Institute.

Preston TR and AR Leng (1986). Supplementation of diets based on fibrous residues and byproducts. pp.373-413. In: F. Sundstøl and E. Owens (eds.), Straw and Other Fibrous Byproducts as Feeds. Development in animal and veterinary sciences (The Netherlands), No.14.Elsevier science publisher BV, Amsterdam, The Netherlands program.

Promma S, Jeenklum P, Indratula T (1993). Production responses of crossbreeding Holstein milking cows fedurea treated rice straw at three different fiber levels.

Teshome D (2009). On-farm Evaluation of Urea Treated Rice Straw and Rice Bran Supplementation on Feed Intake, Milk Yield and Composition Of Fogera Cows, North Western Ethiopia.

Thaintip K, Somkiert P, Phongthorn K, Sour S and Sornthep T (2013). Effect of Fermented By-Product and Rice Straw on Milk Yield and Fatty Acid Composition in Dairy Cows

Upton M (1979). Farm Management in Africa. The principles of production and planning.Oxford University Press, Great Britain. pp. 282-298.
Van SPJ, BJ Robertson and BA Lewis (1991). Methods For Dietary Fiber, Neutral Detergent Fiber, And Non- starch Polysaccharides In Relation To Animal Nutrition. Dairy, Science 74:3583-3597.

Wanapat M, Kang S, Hankla N and Phesatcha k (2013). Effect of rice straw treatment on feed intake, rumen fermentation and milk production in lactating dairy cows. African journal of agricultural research

Yuangklang C, Patipan C, Wongnen C, Vasupen K, Wongsuthavas $\mathrm{S}$, Bureenok $\mathrm{S}$, Panyakaew $\mathrm{P}$ and Khotsakdee J (2009). Effect of rice straw type on nutrient digestion and rumen fermentation in buffalo. 